\title{
Metastases in Prostate Cancer
}

\author{
Federico La Manna, ${ }^{1,3}$ Sofia Karkampouna, ${ }^{1,3}$ Eugenio Zoni, ${ }^{1,3}$ Marta De Menna, ${ }^{1}$ \\ Janine Hensel, ${ }^{2}$ George N. Thalmann, ${ }^{1}$ and Marianna Kruithof-de Julio ${ }^{1}$ \\ ${ }^{1}$ Department of Urology, Inselspital, Bern University Hospital, Department for BioMedical Research, \\ University of Bern, 3008 Bern, Switzerland \\ ${ }^{2}$ Department of Cancer Biology, Metastasis Research Center, University of Texas MD Anderson Cancer Center, \\ Houston, Texas 77030 \\ Correspondence: marianna.kruithofdejulio@dbmr.unibe.ch
}

Prostate cancer (PCa) prognosis and clinical outcome is directly dependent on metastatic occurrence. The bone microenvironment is a favorable metastatic niche. Different biological processes have been suggested to contribute to the osteotropism of PCa such as hemodynamics, bone-specific signaling interactions, and the "seed and soil" hypothesis. However, prevalence of disseminating tumor cells in the bone is not proportional to the actual occurrence of metastases, as not all patients will develop bone metastases. The fate and tumor-reforming ability of a metastatic cell is greatly influenced by the microenvironment. In this review, the molecular mechanisms of bone and soft-tissue metastasis in PCa are discussed. Specific attention is dedicated to the residual disease, novel approaches, and animal models used in oncological translational research are illustrated.

Drostate cancer (PCa) is the most common cancer and the second-leading cause of cancer-associated death in men (Siegel et al. 2014). Because of the progress made in the treatment of the primary tumor, mortality in cancer patients is now increasingly linked to the metastatic disease (Fig. 1) (Sleeman and Steeg 2010). PCa metastasizes to different organs with a propensity to bone (Gandaglia et al. 2013). More than 50 years ago $>20 \%$ of patients presented with bone metastasis at diagnosis (Murphy et al. 1982). Data from older studies report median overall survival times of 30-36 months and a median overall survival of $\sim 18$ months in the castration-resistant setting, which in recent years has improved to a median overall survival of 42 months and 2-year overall survival of $72 \%$ (95\% confidence interval [CI], 68-76) (James et al. 2015). Survival times were influenced by performance status, age, Gleason score, and metastasis distribution. Visceral involvement alone or with bone metastasis is a negative prognostic factor and should be considered a sign of a more aggressive disease in patients presenting with metastatic disease (Gandaglia et al. 2015).

The spine, pelvis, and ribs are the most frequently observed sites of bone metastasis (Kakhki et al. 2013). This distribution is often multifocal, and the more frequent involvement of the axial skeleton suggests an affinity to the hematopoietic active red bone marrow. This is substantiated by the clinical observation that

\footnotetext{
${ }^{3}$ These authors contributed equally to this work.

Editors: Michael M. Shen and Mark A. Rubin

Additional Perspectives on Prostate Cancer available at www.perspectivesinmedicine.org

Copyright (C) 2019 Cold Spring Harbor Laboratory Press; all rights reserved; doi: 10.1101/cshperspect.a033688

Cite this article as Cold Spring Harb Perspect Med 2019;9:a033688
} 


\section{F. La Manna et al.}

A

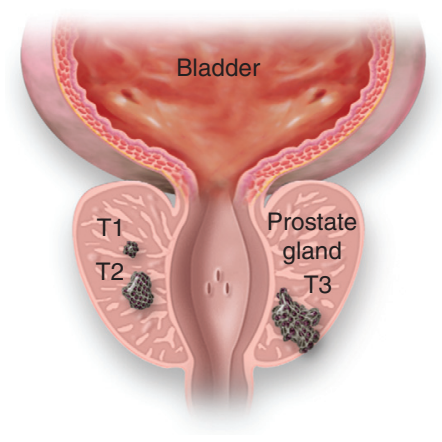

B

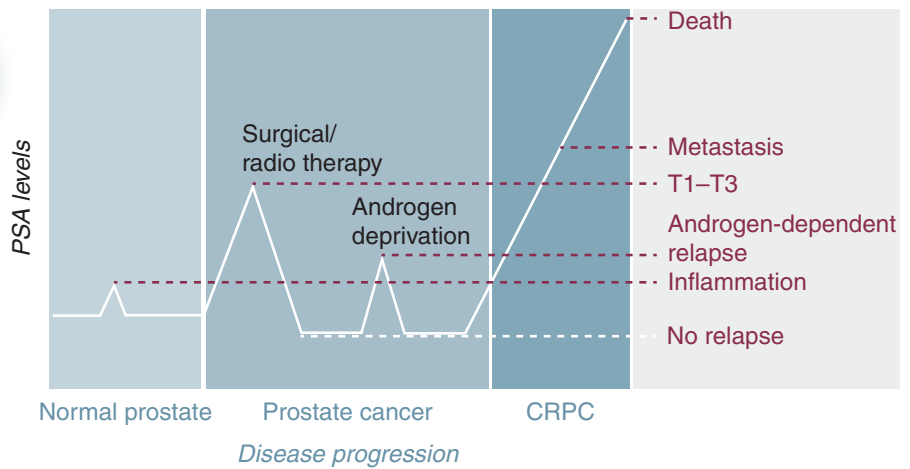

Figure 1. Overview of prostate cancer (PCa) progression and therapeutic options. (A) Schematic drawing of different primary PCa stages, as defined by T category of the TNM staging system: T1, confined, not palpable tumor; T2, confined, palpable tumor; T3, palpable tumor, grown through the prostate capsule and spreading to the neighboring tissues. (B) Diagram of prostate serum antigen (PSA) blood levels over cancer progression. PSA serum level is used as a diagnostic marker to monitor both the progression of the disease and the effectiveness of the treatments received by the patient. CRPC, castrate-resistant prostate cancer.

with extensive metastases to the axial skeleton, secondary (embryological) sites of hematopoiesis may be activated and may become secondary sites of metastasis. Historically anatomical factors, such as the venous Batson's plexus along the spine, were thought to support this process (Batson 1940). Blood flow in the bone marrow of the adult human is about $2.5 \mathrm{~L}$ of blood per minute. Unlike other organs, the arterial supply of the bone marrow ends directly in large vessels (sinusoids). Sinusoids are characterized by an endothelium allowing dynamic opening of pores within the endothelial cells themselves. Blood flow within the sinusoids is slow and nearly stagnant in some areas. These traits not only allow an easy egress of hematopoietic stem cells (HSCs) into the circulation but also facilitate cancer cell extravasation and lodging in the bone marrow. Interesting to note is that sinusoids, which are also part of the spleen, are not prone to be a metastatic site, and this questions the exclusive role of the architecture of the bone marrow sinusoids in the osteotropism of PCa (Hensel and Thalmann 2016).

Despite early detection of the primary tumor, bone metastases are detected in up to $10 \%$ of patients already at initial diagnosis of PCa. Additionally, $20 \%-30 \%$ of the patients subjected to radical prostatectomy (RP) for organ-confined (stage T1-T3) PCa will relapse and fatally progress to advanced disease, in which $70 \%-80 \%$ of those patients will harbor bone metastases. Most likely, the majority of recurrences are caused by disseminated tumor cells (DTCs or occult "micrometastases") that had already colonized the target tissue before the time of diagnosis and treatment of the primary tumor. This strongly suggests that in a significant proportion of early-diagnosed PCa the primary tumor already harbors cancer cells with stem-like cell properties (cancer stem-like cell, CSC-like), which are also able to colonize distant organs (metastasis initiating cells, MICs) (Valastyan and Weinberg 2011). Importantly, the microenvironment that harbors the metastatic site must be favorable to this colonization and potentially characterized by biological and molecular features that support the homing of malignant cells and their growth.

Metastasis is a highly inefficient process, in fact, only $0.001 \%-0.02 \%$ of DTCs eventually colonize to distant organs resulting in tumor growth (Luzzi et al. 1998; Schneider et al. 2005). The metastatic process can be described as a multistep process that is initiated in the primary tumor and results in distant tumor growth. The first step is the acquisition of 
characteristics from a sessile/epithelial to a mesenchymal/invasive phenotype, described as epithelial-to-mesenchymal transition (EMT), which allows the cells to disseminate. This step of "dedifferentiation" is crucial for the acquisition of invasive characteristics and the dissemination of cancer cells from the primary tumor to the neighboring and distant tissues. To form distant metastasis, the DTCs have to leave the primary site, survive in circulation, attach in the vasculature, migrate and colonize, go into dormancy, and reactivate at the distant site. All this is facilitated by the permissive microenvironment. Much effort has been put into the understanding of these processes aiming to identify the best therapeutical window to target either the cancer cells, the microenvironment, or both (Sterling et al. 2011; Weilbaecher et al. 2011).

\section{CIRCULATING AND DISSEMINATING TUMOR CELLS AND THE METASTATIC MICROENVIRONMENT}

\section{The Seed and the Soil Hypothesis}

Stephen Paget, more than 100 years ago, observed in women autopsies that, "in cancer of breast the bones suffer in a special way" (Paget 1889). This landmark observation has led to the "seed and soil" hypothesis that postulates the reciprocal need of the seed (cancer cell) and the soil (microenvironment) so that metastasis can occur in distant individual organs. The uniqueness of the microenvironment in the individual organs (liver, lung, bone, etc.) supports or opposes the colonization events that lead to the secondary tumor growth.

The tumor cells that leave the primary site and enter circulation are defined as circulating tumor cells (CTCs); only a fraction of these cells has the capability to extravasate at a distant site and persist/survive as DTCs. Of these DTCs, an even smaller fraction is capable of forming metastasis (Pantel and Speicher 2015; Yang and Weinberg 2008).

\section{Two Main Models of Metastasis}

The first model hypothesizes that metastasisinitiating cells need to undergo deep molecular rearrangements to proceed through the various steps of the metastatic cascade, and is often referred to as the "phenotypic plasticity model." To leave the primary tumor site, cancer cells must undergo EMT. This process enables them to become more invasive and motile, allowing migration toward gradients of oxygen and nutrients brought by the vasculature associated to the tumor, often leaky, unorganized, and incompletely formed. However, recent literature has pointed out that EMT might be a dispensable process for the occurrence of metastasis but fundamental for the acquisition of chemoresistance (Zheng et al. 2015).

The concept of "epithelial plasticity" being a process that requires somatic mutations and (epi)genetic changes exclusively in the cancer cells is too simplistic. A fundamental contribution to the maintenance and progression of the primary tumor from a confined to an invasive state is provided by different cell types and extracellular matrix (ECM) components, which constitute the stroma (van der Pluijm 2011). It has been documented that cancer cells can "activate" different cellular components of the stroma, such as fibroblasts, and can recruit inflammatory, endothelial, and mesenchymal cells. These cellular components can, in turn, support cancer cell proliferation and invasion (Mueller and Fusenig 2004; Bhowmick and Moses 2005). This combination of environmental factors and molecular properties on the tumor side and stromal side, respectively, allows cancer cells to enter the bloodstream as CTCs (Carmeliet and Jain 2011). The controversy with this might be due to the notion of irreversibility of EMT (Thiery 2002) and the need of cancer cells, once they reached their metastatic site, to undergo mesenchymal-to-epithelial transition (MET) to regain their proliferative and metastatic behavior. This would imply proteome and transcriptome changes that do not seem to be found in the DTCs of several cancers, which appear epithelial (Braun et al. 2000; Schardt et al. 2005; Dasgupta et al. 2017). Cancer cells with metastatic potential would be required to show a high degree of epithelial-mesenchymal plasticity to progress throughout the different stages of the metastatic spread. However, 


\section{F. La Manna et al.}

EMT-associated transcription factors have been shown by a number of groups to be associated with both positive and negative metastatic effects (Yang and Weinberg 2008; Ocaña et al. 2012; Tsai et al. 2012; Vanharanta and Massagué 2013), leaving this a yet open question.

The second model hypothesizes the selection of subpopulations of cancer cells within the tumor that are genetically predisposed for metastasis; this model is frequently referred to as the "genetic" or "clonal" model (Nowell 1976; Ruiz et al. 2011). This model addressed the clinical observation that some metastases do not display a differentiated phenotype. According to this model, clones or subpopulations of tumor-initiating cells bear a set of genetic alterations that cause a permanent activation of EMT features, which render them fit for the metastatic process. These genetic alterations could be either an intrinsic feature of these cancer subpopulations (driver mutations), developed during tumorigenesis (for instance, when the tumorigenic alterations hit a cell early in its process of differentiation, like a tissue stem cell), or an acquired trait (passenger mutations) developed in response to environmental factorslike the selective pressure imposed by treatment with chemotherapeutic agents. Another interesting hypothesis comes from the observation that the CTCs can also be found in clusters. In this scenario, the cancer cells may facilitate their capability to dock and proliferate by taking with them their own "cancer soil" as passenger soil, as described for lung cancer (Fig. 2) (Duda et al. 2010).

In the process of initial seeding, cell-cell interactions and cell adhesion to the ECM play a critical role. The ECM of the growing cancer undergoes numerous alterations in terms of both biochemical and physical properties (i.e., stiffness, elasticity, and tension) (Miles and Sikes 2014). Integrins play a pivotal role in tumor progression, as they can couple ECM-derived mechanical cues with intracellular signaling pathways (Friedland et al. 2009).

Metastatic PCas show higher levels of active $\beta 1$ integrin, which confers both an enhanced capacity to colonize distant organs, through the adhesion to ECM molecules like fibronectin and collagen type I, and a survival advantage, through an increase in the resistance to anoikisthe programmed cell death induced by insufficient adhesion to the growth substrate (Lee et al. 2013; Jin et al. 2014).

Cancer cells also express other integrins, like $\alpha v$ and $\beta 3$, that promote their adherence to a broader variety of proteins of the ECM of other organs, like osteopontin, thrombospondin, vitronectin, fibronectin, intracellular adhesion molecule (ICAM-1), and vascular adhesion molecule (VCAM-1) (Thalmann et al. 1999; Zhao et al. 2007; Lu et al. 2011; Schneider et al. 2011), which has led to the concept of "osteomimicry” by PCa cells (Koeneman et al. 1999). PCa cells also take advantage of the chemokine(C-X-C-motif) axis CXCL12/CXCR4 as homing mechanism to the bone, resulting in an enhanced capacity to contact the bone marrow niche and establish long-term dormancy. Among other compounds, PCa cells secrete the chemokine CXCL16, which boosts the recruitment of bone marrow stromal cells (MSCs). This signaling axis, in turn, promotes the conversion of MSC into cancer-associated fibroblasts (CAFs), which secrete high levels of CXCL12, which potentiate the EMT conversion of cancer cells and up-regulate their expression of the cognate receptor CXCR4 (Jung et al. 2013). Cancer cells also up-regulate the expression of matrix metalloproteases that facilitate extravasation/ migration of the cancer cells (Sun et al. 2004). This process has been described for several cancer types and has therefore become an attractive target for therapeutical treatment of solid tumors (Schneider et al. 2011).

\section{RESIDUAL DISEASE AND TUMOR DORMANCY}

Once disseminated, cancer cells can survive as DTCs at the metastatic site for decades. The dynamics of metastatic outgrowth varies considerably between cells, cancer types, and individual patients. This survival can be defined either as a quiescent (dormant or senescent) state or as an equilibrium, in which, although the disseminated metastatic foci will not grow to overt, clinically relevant metastases, they will 


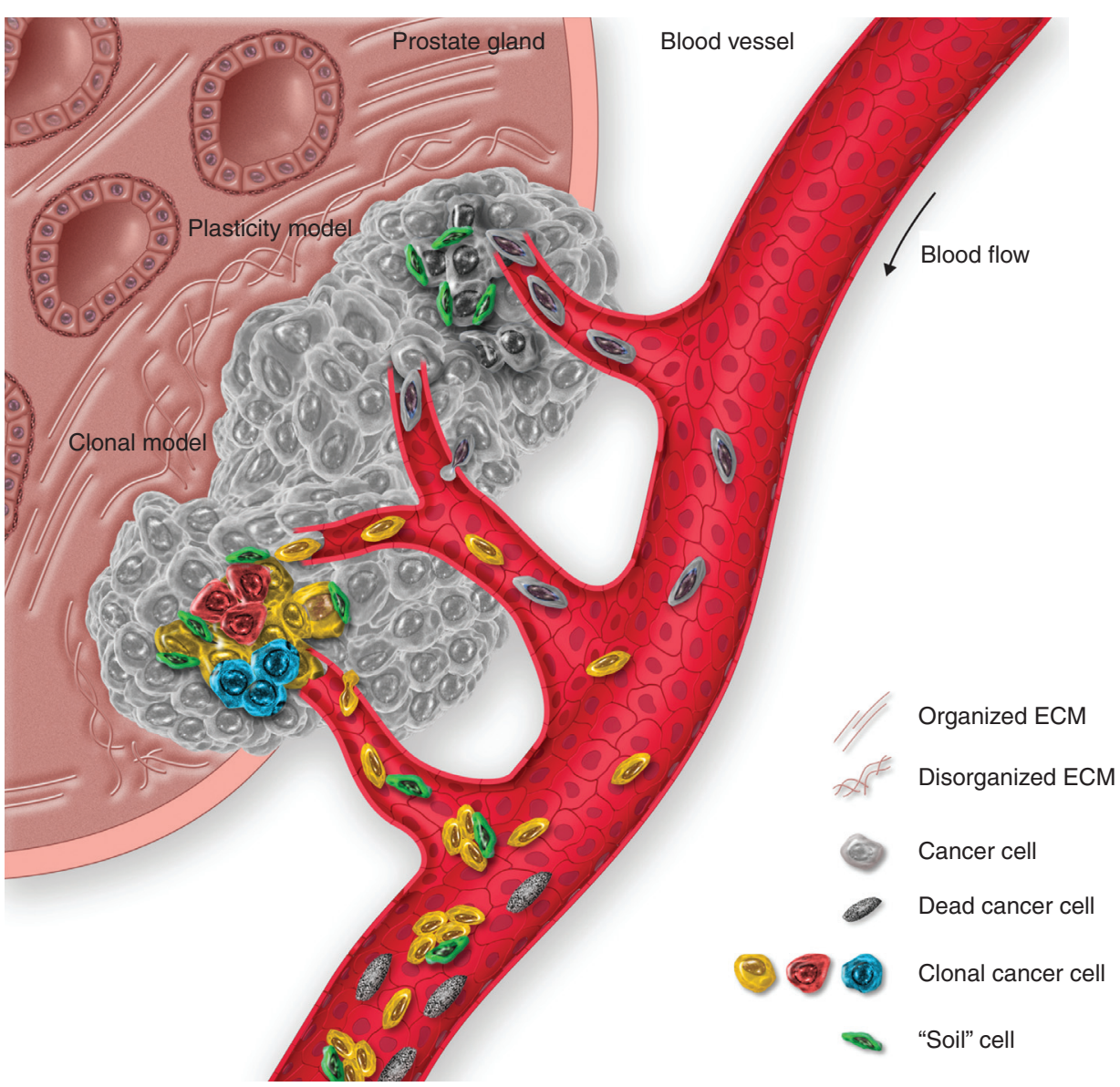

Figure 2. The metastatic spread of prostate cancer (PCa) from the primary site. The primary lesion growth is characterized by a dysregulation of the prostate architecture, inducing changes in the extracellular matrix (ECM) composition and architecture, together with the induction of an inflammatory state that activates stromal cells and favors the recruitment of blood vessels to the lesion. As the tumor recruits new blood vessels, the systemic dissemination of cancer cells (in the form of circulating tumor cells, or CTCs) can take place. Two are the main models that explain the metastatic spread: "plasticity model" and "clonal model." According to the plasticity model, as the cancer cells progress through malignancy, they may collect hits that make them fit for the metastatic process. The clonal model, on the other hand, theorizes that within the heterogeneous cancer cell subpopulations, clones with different fitness are generated, including some with the characteristics required for the metastatic spread. In addition, clusters of cells may form between spreading cancer and stromal cells from the primary lesion, the latter forming the "soil" cells that can facilitate the spreading and the survival of CTC. However, most of the CTCs will not survive in the bloodstream and will circulate as dead CTCs until clearance.

still release cancerous cells into circulation (Ghajar 2015). Dormancy can, in this regard, be induced at a cellular level, in which case the cells undergo a $\mathrm{G}_{0}-\mathrm{G}_{1}$ arrest (Aguirre-Ghiso 2007; Ghajar 2015), or it can be induced at the population level as a cell-depleting event (e.g., apoptosis) (Sherwood et al. 1971; Gimbrone 1972; Aguirre-Ghiso 2007; Rakhra et al. 2010).
This latter hypothesis is supported by the fact that CTCs can still be detected, for instance, in the circulation of breast cancer patients whose primary tumor had been removed and who do not present signs of relapse (Meng 2004; Ghajar 2015). CTCs have also been detected in the circulation of PCa patients after RP, although correlation with patient clinical outcome is still 


\section{F. La Manna et al.}

controversial (Adsan et al. 2002; Morgan and Dearnaley 2014; Thalgott et al. 2015). Persistence of DTCs in the bone marrow of PCa patients after RP, instead, is a predictor of recurrence (Morgan et al. 2009).

One key element that characterizes DTC growth dynamic and confers capacity to disseminate is the interaction with the microenvironment of the target organ and, in particular, with the local perivascular niches.

Given that cancer cells leave the primary site via the lymphatic or vascular site, it is no surprise that DTCs are found in close proximity of the vascular basement membrane (Chambers et al. 2002; Kienast et al. 2010; Ghajar et al. 2013; Price et al. 2016). This particular microenvironment is defined as the perivascular niche and has a central role in normal tissue development and differentiation by homing stem cells and maintaining them in a stem-like state through the balancing of pro- and antiangiogenic factors (Christov et al. 2007; Butler et al. 2010; Goldman and Chen 2011; Xiao et al. 2013).

In $\mathrm{PCa}$, the main site of metastasis is the bone marrow (Bubendorf et al. 2000). Bone marrow is the main site of hematopoiesis in adults, a process in which the long-term, lifelong persistence of the HSCs is temporally associated with the high proliferative rates required to maintain hematological homeostasis (Mendelson and Frenette 2014; Calvi and Link 2015). Therefore, mechanisms must be present in the bone marrow to support both processes. Moreover, the bone marrow is also a site of intense cellular trafficking (Méndez-Ferrer et al. 2008; Mazo et al. 2011; Casanova-Acebes et al. 2013), and its peculiar vasculature structure has the characteristics that best allow this function (Nombela-Arrieta et al. 2013).

It is then conceivable to hypothesize a correlation among the normal stem cell maintenance, the dormancy of the DTCs, and the role of the perivascular niche. The "endosteal" (or "vascular") and the "perivascular" niche have both been described as the two major HSC niches. In the bone marrow, long-term repopulating HSCs have been found both in the endosteal and perivascular spaces, two stem cell niches where HSCs may reside in a state of quiescence, which allows their long-term repopulating abilities and ensures protection against genotoxicity (Cheshier et al. 1999; Cheng 2000; Arai et al. 2004; Nombela-Arrieta et al. 2013). Interestingly, bone marrow stromal cells have been shown to support and promote their fate by protecting them from oxidative stress and limiting their entry into the cell cycle (Ludin et al. 2012).

PCa cells compete with HSCs for the occupancy of the limited niches in the bone marrow (Braun et al. 2005; Zhang et al. 2003), and reducing the niche size hampers dissemination (Shiozawa et al. 2011). However, once the DTCs have occupied ("hijacked") the vascular niche, they acquire a stem cell phenotype (Shiozawa et al. 2016). The acquired stem-like phenotype, together with the protective microenvironment in which PCa DTCs reside, confers DTC a high degree of resistance to therapy (Kobayashi et al. 2011; Chéry et al. 2014). Of particular interest is the active role of a stable microvasculature on the initiation of the metastatic growth (Ghajar 2015).

Once DTCs are awakened from their dormant state, they may start to reform macrometastases of osteoblastic or osteolytic nature, depending on the origin of primary tumor; $\mathrm{PCa}$ leads to mainly osteoblastic lesions, whereas breast cancer leads to osteolytic lesions (Fig. 3) (Logothetis and Lin 2005).

Tumor cells influence and are being influenced by the bone microenvironment, evading from the immune system and acquiring bonerelated properties (osteomimicry, as previously mentioned) (Özdemir et al. 2014). The "preference" of tumor cells to colonize the bone has been attributed to a specific bone-related gene expression signature that tumor cells have before the metastasis, as it has been shown by studies in breast cancer (Kang et al. 2003). Additionally, cancer cells recruit bone marrow stromal cells to the primary site where they become CAFs, which contribute to the metastatic potential of malignant cells (Jung et al. 2013).

\section{BONE METASTASIS: THE VICIOUS CYCLE}

Osteoclast and osteoblasts mediate constantly the dynamic remodeling of the bone tissue. 

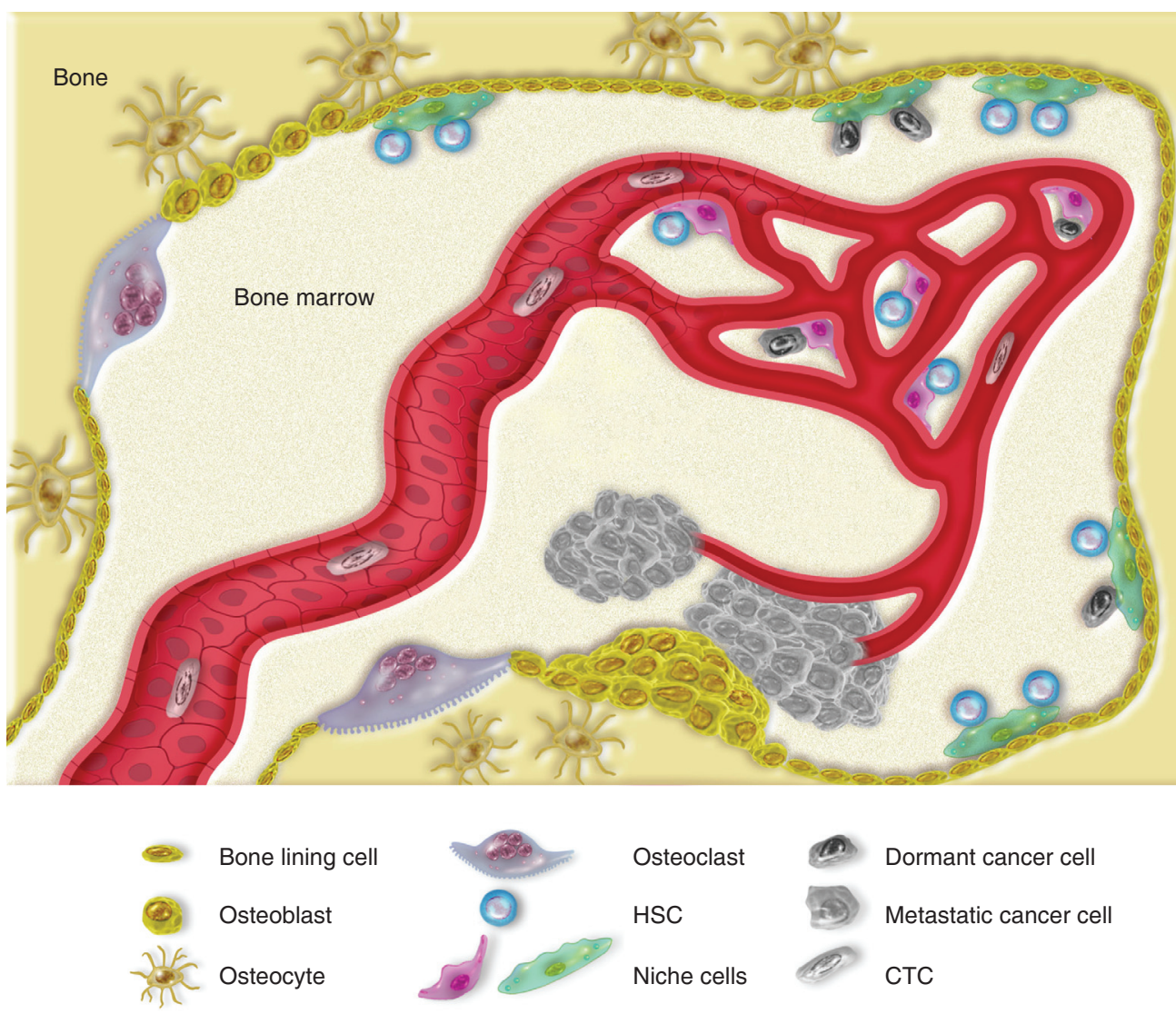

Figure 3. Dissemination of prostate cancer (PCa) cells in the bone marrow: from DTCs to overt metastasis. The hematopoietic bone tissue consists of two main parts: the bone tissue and the bone marrow. Bone is a highly regulated tissue that undergoes constant remodeling to keep its architecture and mechanical properties; as osteoclasts resorb weak bone, skeletal stem cells undergo local expansion, followed by differentiation into osteoblasts. Depending on the local microenvironment and the tissue architecture, osteoblasts will further differentiate either into bone-producing osteocytes or bone-lining cells-namely, the layer of cells that is in contact with the marrow cavities where hematopoiesis occurs. To ensure the lifelong production of blood, hematopoietic stem cells (HSCs) reside in specific areas, or niches, supported by specialized stromal cells (or niche cells) and can be found both at the endosteal and perivascular sides of the bone marrow. Within these niches, HSCs are induced in a state of quiescence, protected from cellular stresses, and prevented from further proliferation. Prostate CTCs may disseminate to the bone marrow and compete with the HSCs for the space in the niches. Within the niches, DTCs could remain dormant for an indefinite amount of time. Eventually, DTCs may exit their dormant state and start proliferating, bending the coupled processes of bone resorption and bone formation to support their growth. Most frequently, this vicious cycle produces hyperplastic bone tissue, eventually forming clinically relevant osteosclerotic metastasis.

Tumor cells produce cytokines (e.g., tumor necrosis factor $\alpha$ [TNF- $\alpha]$, IL-11, VCAM-1, MMP1, Jagged1, parathyroid hormone-related protein $[\mathrm{PTHrP}])$, which stimulate the osteoclast maturation or, indirectly, promote osteoclast differentiation by stimulating bone marrow osteoblast to produce IL-6 and receptor sctivator of nuclear factor $\kappa \mathrm{B}$ (RANKL). Bone matrix resorption then releases transforming growth factor $\beta$ (TGF- $\beta$ ) and insulin-like growth factor-1 (IGF1), which promote proliferation and survival of the cancer cells, closing the circle to what is known as the "vicious cycle," which effectively promotes osteolytic metastasis 
F. La Manna et al.

(Weilbaecher et al. 2011; Ell et al. 2013). However, the use of antiresorptive agents, like bisphosphonates, as strategy to inhibit bone resorption and interfere with bone metastasis revealed no effect on cancer cell proliferation in animal studies (Sasaki et al. 1995; van der Pluijm et al. 2005; Yuen et al. 2006). This suggests that other mechanisms, such as the coupling of angiogenesis and osteogenesis previously mentioned, support tumor cell growth in the bone. Interestingly, microRNA (miRNA) have recently also been reported to play a fundamental role in osteoclastogenesis. Dicer1, Dgcr8, and Ago2 block osteoclast differentiation (Sugatani and Hruska 2009; Mizoguchi et al. 2010), whereas ectopic expression of miR-155 (Mann et al. 2010; Mizoguchi et al. 2010; Zhang et al. 2012) and repression of miR-21(Sugatani et al. 2011) inhibit osteoclast differentiation. Recently, it has been shown that osteoclastogenesis is inhibited by that miR-133a, -141, and -219 , whereas miR-190 might inhibit osteoclasts differentiation (Ell et al. 2013). Although bone lesions in PCa are typically osteoblastic (Mundy 2002; Logothetis and Lin 2005), the coexistence of osteobastic and osteolytic responses have been documented (Theriault 2012). Among the variety of factors that orchestrate the balance between osteoclastic- and osteoblastic-activity, TGF- $\beta$ and Wnt signaling are two fundamental networks that regulate the maintenance and expansion of osteoprogenitor cells and their differentiation toward osteoblasts.

The canonical Wnt signaling pathway seems to play a role in the onset of castration resistance in PCa (Wang et al. 2008). Moreover, alterations of canonical Wnt signaling, such as modulation of the dickkopf (DKK) genes or mutations of sclerostin (SOST), which inhibits LRP5, contribute to disrupt bone formation, a process whereby Wnt signaling exerts a crucial role (Semenov et al. 2005). Wnt signaling also induces the expression of osteoprotegerin (OPG), which prevents the binding of RANKL to RANK, thereby inhibiting osteoclast function and leading to a "bone active effect" (Rentsch et al. 2009).

The TGF- $\beta$ superfamily also exerts a major role in the context of the bone microenviron- ment and its remodeling in PCa. TGF- $\beta$ supports the development of bone metastasis from PCa in animal models (Fournier et al. 2015). In particular, bone morphogenetic proteins (BMPs) and Noggin, which antagonizes BMP signaling, are functionally involved in skeletal and joints morphogenesis, bone remodeling, and in different cellular processes, including osteogenesis (Chen et al. 2004). One of the main BMPs involved in the recruitment of osteoblasts is represented by BMP6 (Dai et al. 2005). On the other hand, the recruitment of osteoclasts and stimulation of their activity in PCa is mediated by MMP-7, which cleaves RANKL (thereby stimulating osteoclastogenesis) (Lynch et al. 2005), and Noggin, which antagonizes BMPs and impairs bone formation (Schwaninger et al. 2007; Secondini et al. 2011).

\section{SOFT-TISSUE METASTASIS}

The common paradigm of tumor progression is that tumor cells from an advanced tumor unidirectionally migrate to lymphatic sites and then toward distant organs to form secondary metastases (Halsted 1894). This view has been challenged by recent studies showing that tumor cells can, at any point of tumor formation, multidirectionally seed to distant organs, whereas secondary and tertiary metastases can form independently from the primary clone (Haffner et al. 2013; Beltran et al. 2016). Presence of lymph node (LN) metastases is a frequent consequence of $\mathrm{PCa}$ associated with high risk, poorer outcome, and limited therapeutic possibilities, such as surgical resection of pelvic LN, radiotherapy, and androgen deprivation therapy (ADT). Surgical resection may not be effective in removing all LN metastases because of imaging and detection limitations, whereas multiple surgeries are not an option because of postoperative scarring and other complications (Sankineni et al. 2015). Disease-free survival is directly dependent on LN staging and the number of metastases. The frequency of mitochondrial mutations, affecting the metabolism of tumor cells, is lower in LN, liver, and lung metastases compared with bone metastases (Arnold et al. 2015). Visceral metastases in men with metastat- 
ic, castration-resistant prostate cancer (CRPC) constitute a high prevalence and are linked to poor outcomes (Halabi et al. 2014). B-cell lymphoma 2 (BCL-2), BCL-XL, myeloid cell leukemia 1 (MCL-1) and survivin expression has been measured in primary PCas and small cohorts of lymph node and bone metastases (Krajewska et al. 1996, 2003; Zellweger et al. 2005). Their expression has been associated with transgression of the prostate capsule, risk of relapse, and metastatic progression (Scherr et al. 1999). Interestingly, soft-tissue metastasis transcriptional and protein profile differs from that of bone metastasis. In particular, nuclear survivin was observed in soft-tissue metastasis, whereas bone metastases show relative overexpression of cytoplasmatic survivin, suggesting that cancer cell apoptosis-inducing drugs may exert various effects and may show very different efficacies, depending on the site of the metastasis. Additionally, in liver and LN tissues, the angiogenic expression profile was different (Morrissey et al. 2008), suggesting that factors involved in tumor vascular recruitment and maintenance may also be affected by the microenvironment.

PCa adenocarcinomas show osteotropism, resulting in osteoblastic and osteolytic lesions, however, neuroendocrine (NE) tumors metastasize prevalently to visceral sites (Marcus et al. 2012). NE cases, both the spontaneous ones and those arising following ADT therapy, are associated with low prostate serum antigen (PSA) values, visceral metastases, and poor survival (Palmgren et al. 2007).

The mechanisms of different organotropic properties of various PCa types remain to be elucidated.

\section{EXPERIMENTAL MODELS OF BONE METASTASIS}

With the life expectancy of men increasing, PCa has become a major medical problem. Once the tumor has metastasized, outcome is dismal. Research on PCa bone metastases has been hampered by the limited number of experimental models available.

The reasons for this are multiple: poor growth potential of human prostate tumor tis- sue in nude mice, slow development of immune deficient mice strains, limited cell lines, and lack of spontaneous PCa in animals with the exception of $\mathrm{ACI} / \mathrm{Seg}$ and Lobund-Wistar rats. With the advent of mutant nude mice with a deficient cell-mediated immune response and only slightly impaired humoral antibody formation, xenografts of cell lines and human tumor tissue became possible and opened a new era of research (van Weerden and Romijn 2000), albeit still impeded by an increased natural killer (NK) cell activity in these animals. A number of preclinical models using state-of-the-art molecular imaging for cell tracking and drug response have been developed (Buijs et al. 2007; Eaton et al. 2010; van den Hoogen et al. 2010).

Cancer cell tracking and drug response can be studied by intracardiac delivery of human PCa cells that stably express either bioluminescence (e.g., luciferase) or fluorescence (e.g., near infrared fluorescent [NIRF] proteins or green fluorescent protein [GFP]) reporters as a model of bone metastasis. Orthotopic and intraosseous cell delivery models are used for the study of primary PCa and metastatic PCa and, in particular, the interactions between cancer cells and bone microenvironment (Dai et al 2016).

Several efforts to obtain xenografts from patient samples ( patient-derived xenografts, PDX) have been attempted. The model PC-82 was the first androgen-dependent PCa xenograft established, achieving a success rate of about 5\% over many years (Hoehn et al. 1980; van Weerden and Romijn 2000). In vivo growth rate was improved by the introduction of Matrigel, in which cells were suspended and mixed with $\mathrm{Ma}$ trigel, allowing the propagation of the CWR (Case Western Reserve) xenograft tumor series, such as the CWR-22 xenograft (Pretlow et al. 1991, 1993). Seven additional xenograft models were established in $\mathrm{BALB} / \mathrm{c}$ mice using intact tumor piece implantation and testosterone administration from primary and metastatic PCa (LN and skin) (van Weerden et al. 1996). Bone and LN metastasis-derived PCa xenografts were developed by coinjection of tumor cells with Matrigel in severe combined immunodeficient (SCID) mice (Klein et al. 1997). The bone me- 


\section{F. La Manna et al.}

tastasis-derived LAPC-9 model is dependent on androgens for growth, secretes PSA, and shows spontaneous tumor reinitiation after prolonged androgen deprivation (Craft et al. 1999). Another model (Garcia et al. 2014) that has been used to study the transition from androgen-dependent to -resistant tumor growth is the LN metastasis-derived LAPC-4 model, established by the same group (Craft et al. 1999).

The BM18 PCa xenograft model, developed from a bone metastasis biopsy, retains androgen-dependent growth and survival properties, whereas it recapitulates the luminal phenotype observed in human PCa with stem cell characteristics similar to those of castration-resistant NKX3.1 cells (CARNs) described in the mouse (Wang et al. 2009; Germann et al. 2012). Similar results were also achieved in the $\mathrm{LuCaP}$ model (Ellis et al. 1996) and MDA model (Navone et al. 1997).

Taking into account the importance of stromal-epithelial interactions in tumor development and progression, a cell-cell recombination model was generated by the coinoculation of nontumorigenic LNCaP cells (Horoszewicz et al. 1983) with organ-specific fibroblasts from the bone into athymic nude mice, showing the ability to form solid tumors (Gleave et al. 1991). By altering the stromal and hormonal environment in vivo, an androgen-independent, tumorigenic LNCaP subline, C4-2, capable of growing tumors in the castrated host was derived. C4-2 cells secrete PSA autonomously and metastasize to the LN and bone with an incidence of $11 \%-50 \%$, while showing a higher incidence of axial skeleton metastases in castrated hosts. From C4-2 osseous metastases, several cell lines were isolated and denoted as B2, B3, B4, and B5 (Thalmann et al. 2000).

In recent years, several genetically engineered mouse models (GEMMs) of PCa have been established that recapitulate the stages of PCa development, from PIN lesions to localized and invasive adenocarcinoma, to LN metastasis. Telomerase reactivation in the prostate-specific probasin $(\mathrm{PB})$ promoter-driven Smad4 conditional knockout, TP53/PTEN double null model (PB-TP53/PTEN) leads to prostate tumors that progress to bone metastases (Ding et al. 2012).
However, there are limited GEMMs that progress to bone metastases (Grabowska et al. 2014), which can provide insight on the mechanisms of human PCa metastatic cues.

\section{BONE METASTASES IN THE CLINIC}

Metastatic PCa remains an important clinical problem given the growing number of men with advanced disease, its impact on the quality of life, and, ultimately, as a cause of mortality. Osteoblastic bone lesions to the axial skeleton are the most common metastasis in men with advanced PCa. Palliative treatment is a priority, with the goals of relieving pain, improving mobility, and preventing complications such as pathologic fractures or epidural cord compression.

ADT remains the treatment for metastatic $\mathrm{PCa}$, and whereas this reduces the symptoms and tumor growth, recurrence of CRPC is almost certain. Histopathology of end-stage bone metastases acquired at autopsy or a result of surgical resections for spinal cord compressions or pathological fractures (Maitland and Collins 2008; Collins et al. 2005) has shown that, even within an individual patient, bone metastases are heterogeneous. It is important to note that, although nuclear androgen receptor (AR) staining is generally prominent in most cells, non-NE, AR-negative tumor cells are clearly observed in both CRPC and treatmentnaïve metastasis (Colombel et al. 2012). These findings indicate that AR-independent cell survival in the bone microenvironment does occur, and any mechanisms that contribute to such survival are of great interest. Heterogeneity of metastatic disease suggests that second generation, AR-directed therapies such as abiraterone and enzalutamide will most likely need to be conjoined by therapies directed against nonAR pathways and bone-targeting therapies.

ADT increases bone resorption, reduces mineral density, and increases risk of fracture, thus, indirectly leading to occurrence of bone metastasis in CRPC patients (Ottewell et al. 2014). Bisphosphonates have been shown to prevent bone loss associated with ADT, however, a positive effect on fracture prevention is lacking. Bisphosphonates aside current treatments 
of bone metastases include surgery, bone-targeted radiopharmaceuticals, and denosumab.

Denosumab is a Food and Drug Administration (FDA)-approved humanized monoclonal antibody that binds to RANKL, a key factor in the pathway for osteoclast formation and activation, as previously discussed. ADT patients treated with Denosumab showed increased bone mineral density and reduction in vertebral fractures (Smith et al. 2009).

Currently, the only FDA-approved bonetargeting radioisotopes for patients with symptomatic metastatic CRPC are Strontium-89 chloride (Sr-89) and Samarium-153 lexidronam (Sm-153). Multiple clinical trials have shown both to be effective agents for bone pain palliation. Radium-223 chloride (Ra-223) is the first radiopharmaceutical drug to show a prolongation of overall survival in these patients and palliative benefits (Goyal and Antonarakis 2012).

\section{ACKNOWLEDGMENT}

The authors acknowledge somersault18:24 BVBA for drawing the figures.

\section{REFERENCES}

Adsan Ö, Cecchini MG, Bisoffi M, Wetterwald A, Klima I, Danuser HJ, Studer UE, Thalmann GN. 2002. Can the reverse transcriptase-polymerase chain reaction for prostate specific antigen and prostate specific membrane antigen improve staging and predict biochemical recurrence? BJU Int 90: 579-585.

Aguirre-Ghiso JA. 2007. Models, mechanisms and clinical evidence for cancer dormancy. Nat Rev Cancer 7: 834846.

Arai F, Hirao A, Ohmura M, Sato H, Matsuoka S, Takubo K, Ito K, Koh GY, Suda T. 2004. Tie2/Angiopoietin-1 signaling regulates hematopoietic stem cell quiescence in the bone marrow niche. Cell 118: 149-161.

Arnold RS, Fedewa SA, Goodman M, Osunkoya AO, Kissick HT, Morrissey C, True LD, Petros JA. 2015. Bone metastasis in prostate cancer: Recurring mitochondrial DNA mutation reveals selective pressure exerted by the bone microenvironment. Bone 78: 81-86.

Batson OV. 1940. The function of the vertebral veins and their rôle in the spread of metastases. Ann Surgery 112: 138-149.

Beltran H, Prandi D, Mosquera JM, Benelli M, Puca L, Cyrta J, Marotz C, Giannopoulou E, Chakravarthi BV, Varambally S, et al. 2016. Divergent clonal evolution of castration-resistant neuroendocrine prostate cancer. Nat Med 22: 298-305.
Bhowmick NA, Moses HL. 2005. Tumor-stroma interactions. Oncog Cell Proliferation 15: 97-101.

Braun S, Pantel K, Muller P, Janni W, Hepp F, Kentenich CRM, Gastroph S, Wischnik A, Dimpfl T, Kindermann G, et al. 2000. Cytokeratin-positive cells in the bone marrow and survival of patients with stage I, II, or III breast cancer. N Engl J Med 342: 525-533.

Braun S, Vogl FD, Naume B, Janni W, Osborne MP, Coombes RC, Schlimok G, Diel IJ, Gerber B, Gebauer G, et al. 2005. A pooled analysis of bone marrow micrometastasis in breast cancer. N Engl J Med 353: 793-802.

Bubendorf L, Schopfer A, Wagner U, Sauter G, Moch H, Willi N, Gasser TC, Mihatsch MJ. 2000. Metastatic patterns of prostate cancer: An autopsy study of 1,589 patients. Human Pathol 31: 578-583.

Buijs JT, Rentsch CA, van der Horst G, van Overveld PGM, Wetterwald A, Schwaninger R, Henriquez NV, Dijke Ten P, Borovecki F, Markwalder R, et al. 2007. BMP7, a putative regulator of epithelial homeostasis in the human prostate, is a potent inhibitor of prostate cancer bone metastasis in vivo. Am J Pathol 171: 1047-1057.

Butler JM, Kobayashi H, Rafii S. 2010. Instructive role of the vascular niche in promoting tumour growth and tissue repair by angiocrine factors. Nat Rev Cancer 10: 138-146.

Calvi LM, Link DC. 2015. The hematopoietic stem cell niche in homeostasis and disease. Blood 126: 2443-2451.

Carmeliet P, Jain RK. 2011. Principles and mechanisms of vessel normalization for cancer and other angiogenic diseases. Nat Rev Drug Discov 10: 417-427.

Casanova-Acebes M, Pitaval C, Weiss LA, Nombela-Arrieta C, Chèvre R, A-González N, Kunisaki Y, Zhang D, van Rooijen N, Silberstein LE, et al. 2013. Rhythmic modulation of the hematopoietic niche through neutrophil clearance. Cell 153: 1025-1035.

Chambers AF, Groom AC, MacDonald IC. 2002. Dissemination and growth of cancer cells in metastatic sites. Nat Rev Cancer 2: 563-572.

Chen D, Zhao M, Mundy GR. 2004. Bone morphogenetic proteins. Growth Factors 22: 233-241.

Cheng T. 2000. Hematopoietic stem cell quiescence maintained by p21cip1/waf1. Science 287: 1804-1808.

Chéry L, Lam H-M, Coleman I, Lakely B, Coleman R, Larson S, Aguirre-Ghiso JA, Xia J, Gulati R, Nelson PS, et al. 2014. Characterization of single disseminated prostate cancer cells reveals tumor cell heterogeneity and identifies dormancy associated pathways. Oncotarget 5: 9939-9951.

Cheshier SH, Morrison SJ, Liao X, Weissman IL. 1999. In vivo proliferation and cell cycle kinetics of long-term selfrenewing hematopoietic stem cells. Proc Natl Acad Sci 96: 3120-3125.

Christov C, Chretien F, Abou-Khalil R, Bassez G, Vallet G, Authier FJ, Bassaglia Y, Shinin V, Tajbakhsh S, Chazaud B, et al. 2007. Muscle satellite cells and endothelial cells: Close neighbors and privileged partners. Mol Biol Cell 18: 1397-1409.

Collins AT, Berry PA, Hyde C, Stower MJ, Maitland NJ. 2005. Prospective identification of tumorigenic prostate cancer stem cells. Cancer Res 65: 10946-10951.

Colombel M, Eaton CL, Hamdy F, Ricci E, van der Pluijm G, Cecchini M, Mege-Lechevallier F, Clézardin P, Thalmann G. 2012. Increased expression of putative cancer stem cell 
F. La Manna et al.

markers in primary prostate cancer is associated with progression of bone metastases. Prostate 72: 713-720.

Craft N, Shostak Y, Carey M, Sawyers CL. 1999. A mechanism for hormone-independent prostate cancer through modulation of androgen receptor signaling by the HER-2/neu tyrosine kinase. Nat Med 5: 280-285.

Dai J, Keller J, Zhang J, Lu Y, Yao Z, Keller ET. 2005. Bone morphogenetic protein 6 promotes osteoblastic prostate cancer bone metastases through a dual mechanism. Cancer Res 65: 8274-8285.

Dai J, Hensel J, Wang N, Kruithof-de Julio M, Shiozawa Y 2016. Mouse models for studying prostate cancer bone metastasis. Bonekey Rep 5: 777.

Dasgupta A, Lim AR, Ghajar CM. 2017. Circulating and disseminated tumor cells: Harbingers or initiators of metastasis? Mol Oncol 11: 40-61.

Ding Z, Wu CJ, Jaskelioff M, Ivanova E, Kost-Alimova M, Protopopov A, Chu GC, Wang G, Lu X, Labrot ES, et al. 2012. Telomerase reactivation following telomere dysfunction yields murine prostate tumors with bone metastases. Cell 148: 896-907.

Duda DG, Duyverman AMMJ, Kohno M, Snuderl M, Steller EJA, Fukumura D, Jain RK. 2010. Malignant cells facilitate lung metastasis by bringing their own soil. Proc Natl Acad Sci 107: 21677-21682.

Eaton CL, Colombel M, van der Pluijm G, Cecchini M, Wetterwald A, Lippitt J, Rehman I, Hamdy F, Thalman G. 2010. Evaluation of the frequency of putative prostate cancer stem cells in primary and metastatic prostate cancer. Prostate 70: 875-882.

Ell B, Mercatali L, Ibrahim T, Campbell N, Schwarzenbach H, Pantel K, Amadori D, Kang Y. 2013. Tumor-induced osteoclast miRNA changes as regulators and biomarkers of osteolytic bone metastasis. Cancer Cell 24: 542-556.

Ellis WJ, Vessella RL, Buhler KR, Bladou F, True LD, Bigler SA, Curtis D, Lange PH. 1996. Characterization of a novel androgen-sensitive, prostate-specific antigen-producing prostatic carcinoma xenograft: LuCaP 23. Clin Cancer Res 2: 1039-1048.

Fournier PGJ, Juárez P, Jiang G, Clines GA, Niewolna M, Kim HS, Walton HW, Peng XH, Liu Y, Mohammad KS, et al. 2015. The TGF- $\beta$ signaling regulator PMEPA1 suppresses prostate cancer metastases to bone. Cancer Cell 27: 809-821.

Friedland JC, Lee MH, Boettiger D. 2009. Mechanically activated integrin switch controls $\alpha_{5} \beta_{1}$ function. Science 323: 642-644.

Gandaglia G, Abdollah F, Schiffmann J, Trudeau V, Shariat SF, Kim SP, Perrotte P, Montorsi F, Briganti A, Trinh QD, et al. 2013. Distribution of metastatic sites in patients with prostate cancer: A population-based analysis. Prostate 74: 210-216.

Gandaglia G, Karakiewicz PI, Briganti A, Passoni NM, Schiffmann J, Trudeau V, Graefen M, Montorsi F, Sun M. 2015. Impact of the site of metastases on survival in patients with metastatic prostate cancer. Eur Urol 68: 325-334.

Garcia RR, Masoodi KZ, Pascal LE, Nelson JB, Wang Z 2014. Growth of LAPC4 prostate cancer xenograft tumor is insensitive to $5 \alpha$-reductase inhibitor dutasteride. $A m J$ Clin Exp Urol 2: 82-91.
Germann M, Wetterwald A, Guzmán-Ramírez N, van der Pluijm G, Culig Z, Cecchini MG, Williams ED, Thalmann GN. 2012. Stem-like cells with luminal progenitor phenotype survive castration in human prostate cancer. Stem Cells 30: 1076-1086.

Ghajar CM. 2015. Metastasis prevention by targeting the dormant niche. Nat Rev Cancer 15: 238-247.

Ghajar CM, Peinado H, Mori H, Matei IR, Evason KJ, Brazier H, Almeida D, Koller A, Hajjar KA, Stainier DY, et al. 2013. The perivascular niche regulates breast tumour dormancy. Nat Cell Biol 15: 807-817.

Gimbrone MA. 1972. Tumor dormancy in vivo by prevention of neovascularization. J Exp Med 136: 261-276.

Gleave M, Hsieh JT, Gao CA, von Eschenbach AC, Chung LW. 1991. Acceleration of human prostate cancer growth in vivo by factors produced by prostate and bone fibroblasts. Cancer Res 51: 3753-3761.

Goldman SA, Chen Z. 2011. Perivascular instruction of cell genesis and fate in the adult brain. Nat Neurosci 14: 1382 1389.

Goyal J, Antonarakis ES. 2012. Bone-targeting radiopharmaceuticals for the treatment of prostate cancer with bone metastases. Cancer Lett 323: 135-146.

Grabowska MM, DeGraff DJ, Yu X, Jin RJ, Chen Z, Borowsky AD, Matusik RJ. 2014. Mouse models of prostate cancer: Picking the best model for the question. Cancer Metastasis Rev 33: 377-397.

Haffner MC, Mosbruger T, Esopi DM, Fedor H, Heaphy CM, Walker DA, Adejola N, Gurel M, Hicks J, Meeker AK, et al. 2013. Tracking the clonal origin of lethal prostate cancer. J Clin Invest 123: 4918-4922.

Halabi S, Kelly WK, Zhou H, Armstrong AJ, Quinn D, Fizazi K, Solomon NC, Tannock I, Petrylak DP, Morris MJ, et al. 2014. The site of visceral metastases (mets) to predict overall survival (OS) in castration-resistant prostate cancer (CRPC) patients (pts): A meta-analysis of five phase III trials. J Clin Oncol 32: 5002-5002.

Halsted WS. 1894. The results of operations for the cure of cancer of the breast performed at the Johns Hopkins Hospital from June, 1889, to January, 1894. Ann Surg 20: $497-555$

Hensel J, Thalmann GN. 2016. Biology of bone metastases in prostate cancer. Urology 92: 6-13.

Hoehn W, Schroeder FH, Reimann JF, Joebsis AC, Hermanek P. 1980. Human prostatic adenocarcinoma: Some characteristics of a serially transplantable line in nude mice (PC 82). Prostate 1: 95-104.

Horoszewicz JS, Leong SS, Kawinski E, Karr JP, Rosenthal H, Chu TM, Mirand EA, Murphy GP. 1983. LNCaP model of human prostatic carcinoma. Cancer Res 43: 1809-1818.

James ND, Spears MR, Clarke NW, Dearnaley DP, de Bono JS, Gale J, Hetherington J, Hoskin PJ, Jones RJ, Laing R, et al. 2015. Survival with newly diagnosed metastatic prostate cancer in the "docetaxel era": Data from 917 patients in the control arm of the STAMPEDE Trial (MRC PR08, CRUK/06/019). Eur Urol 67: 1028-1038.

Jin JK, Tien PC, Cheng CJ, Song JH, Huang C, Lin SH, Gallick GE. 2014. Talin1 phosphorylation activates $\beta 1$ integrins: A novel mechanism to promote prostate cancer bone metastasis. Oncogene 34: 1811-1821. 
Jung Y, Kim JK, Shiozawa Y, Wang J, Mishra A, Joseph J, Berry JE, McGee S, Lee E, Sun H, et al. 2013. Recruitment of mesenchymal stem cells into prostate tumours promotes metastasis. Nat Commun 4: 1795.

Kakhki VR, Anvari K, Sadeghi R, Mahmoudian AS, Torabian-Kakhki M. 2013. Pattern and distribution of bone metastases in common malignant tumors. Nucl Med Rev Cent East Eur 16: 66-69.

Kang Y, Siegel PM, Shu W, Drobnjak M, Kakonen SM, Cordón-Cardo C, Guise TA, Massagué J. 2003. A multigenic program mediating breast cancer metastasis to bone Cancer Cell 3: 537-549.

Kienast Y, von Baumgarten L, Fuhrmann M, Klinkert WE, Goldbrunner R, Herms J, Winkler F. 2010. Real-time imaging reveals the single steps of brain metastasis formation. Nat Med 16: 116-122.

Klein KA, Reiter RE, Redula J, Moradi H, Zhu XL, Brothman AR, Lamb DJ, Marcelli M, Belldegrun A, Witte ON, et al. 1997. Progression of metastatic human prostate cancer to androgen independence in immunodeficient SCID mice. Nat Med 3: 402-408.

Kobayashi A, Okuda H, Xing F, Pandey PR, Watabe M, Hirota S, Pai SK, Liu W, Fukuda K, Chambers C, et al. 2011. Bone morphogenetic protein 7 in dormancy and metastasis of prostate cancer stem-like cells in bone. J Exp Med 208: 2641-2655.

Koeneman KS, Yeung F, Chung LWK. 1999. Osteomimetic properties of prostate cancer cells: A hypothesis supporting the predilection of prostate cancer metastasis and growth in the bone environment. Prostate 39: 246-261.

Krajewska M, Krajewski S, Epstein JI, Shabaik A, Sauvageot J, Song K, Kitada S, Reed JC. 1996. Immunohistochemical analysis of bcl-2, bax, bcl-X, and mcl-1 expression in prostate cancers. Am J Pathol 148: 1567-1576.

Krajewska M, Krajewski S, Banares S, Huang X, Turner B, Bubendorf L, Kallioniemi OP, Shabaik A, Vitiello A, Peehl D, et al. 2003. Elevated expression of inhibitor of apoptosis proteins in prostate cancer. Clin Cancer Res 9: 49144925.

Lee YC, Jin JK, Cheng CJ, Huang CF, Song JH, Huang M, Brown WS, Zhang S, Yu-Lee LY, Yeh ET, et al. 2013. Targeting constitutively activated 1 integrins inhibits prostate cancer metastasis. Mol Cancer Res 11: 405-417.

Logothetis CJ, Lin SH. 2005. Osteoblasts in prostate cancer metastasis to bone. Nat Rev Cancer 5: 21-28.

Lu X, Mu E, Wei Y, Riethdorf S, Yang Q, Yuan M, Yan J, Hua Y, Tiede BJ, Lu X, et al. 2011. VCAM-1 promotes osteolytic expansion of indolent bone micrometastasis of breast cancer by engaging $\alpha 4 \beta 1$-positive osteoclast progenitors. Cancer Cell 20: 701-714.

Ludin A, Itkin T, Gur-Cohen S, Mildner A, Shezen E, Golan K, Kollet O, Kalinkovich A, Porat Z, D'Uva G, et al. 2012. Monocytes-macrophages that express $\alpha$-smooth muscle actin preserve primitive hematopoietic cells in the bone marrow. Nat Immunol 13: 1072-1082.

Luzzi KJ, MacDonald IC, Schmidt EE, Kerkvliet N, Morris VL, Chambers AF, Groom AC. 1998. Multistep nature of metastatic inefficiency. Am J Pathol 153: 865-873.

Lynch CC, Hikosaka A, Acuff HB, Martin MD, Kawai N, Singh RK, Vargo-Gogola TC, Begtrup JL, Peterson TE, Fingleton B, et al. 2005. MMP-7 promotes prostate can- cer-induced osteolysis via the solubilization of RANKL. Cancer Cell 7: 485-496.

Maitland NJ, Collins AT. 2008. Prostate cancer stem cells: A new target for therapy. J Clin Oncol 26: 2862-2870.

Mann M, Barad O, Agami R, Geiger B, Hornstein E. 2010. miRNA-based mechanism for the commitment of multipotent progenitors to a single cellular fate. Proc Natl Acad Sci 107: 15804.

Marcus DM, Goodman M, Jani AB, Osunkoya AO, Rossi PJ. 2012. A comprehensive review of incidence and survival in patients with rare histological variants of prostate cancer in the United States from 1973 to 2008. Prostate Cancer Prostatic Dis 15: 283-288.

Mazo IB, Massberg S, von Andrian UH. 2011. Hematopoietic stem and progenitor cell trafficking. Trends Immunol 32: 493-503

Mendelson A, Frenette PS. 2014. Hematopoietic stem cell niche maintenance during homeostasis and regeneration. Nat Med 20: 833-846.

Méndez-Ferrer S, Lucas D, Battista M, Frenette PS. 2008. Haematopoietic stem cell release is regulated by circadian oscillations. Nature 452: 442-447.

Meng S. 2004. Circulating tumor cells in patients with breast cancer dormancy. Clin Cancer Res 10: 8152-8162.

Miles FL, Sikes RA. 2014. Insidious changes in stromal matrix fuel cancer progression. Mol Cancer Res 12: 297-312.

Mizoguchi F, Izu Y, Hayata T, Hemmi H, Nakashima K, Nakamura T, Kato S, Miyasaka N, Ezura Y, Noda M. 2010. Osteoclast-specific Dicer gene deficiency suppresses osteoclastic bone resorption. J Cell Biochem 109: 866-875.

Morgan SC, Dearnaley DP. 2014. Additional therapy for high-risk prostate cancer treated with surgery: What is the evidence? Exp Rev Anticancer Ther 9: 939-951.

Morgan TM, Lange PH, Porter MP, Lin DW, Ellis WJ, Gallaher IS, Vessella RL. 2009. Disseminated tumor cells in prostate cancer patients after radical prostatectomy and without evidence of disease predicts biochemical recurrence. Clin Cancer Res 15: 677-683.

Morrissey C, True LD, Roudier MP, Coleman IM, Hawley S, Nelson PS, Coleman R, Wang YC, Corey E, Lange PH, et al. 2008. Differential expression of angiogenesis associated genes in prostate cancer bone, liver and lymph node metastases. Clin Exp Metastasis 25: 377-388.

Mueller MM, Fusenig NE. 2004. Friends or foes-Bipolar effects of the tumour stroma in cancer. Nat Rev Cancer 4: 839-849.

Mundy GR. 2002. Metastasis: Metastasis to bone: Causes, consequences and therapeutic opportunities. Nat Rev Cancer 2: 584-593.

Murphy GP, Natarajan N, Pontes JE, Schmitz RL, Smart CR, Schmidt JD, Mettlin C. 1982. The national survey of prostate cancer in the United States by the American College of Surgeons. J Urol 127: 928-934.

Navone NM, Olive M, Ozen M, Davis R, Troncoso P, Tu SM, Johnston D, Pollack A, Pathak S, von Eschenbach AC, et al. 1997. Establishment of two human prostate cancer cell lines derived from a single bone metastasis. Clin Cancer Res 3: 2493-2500.

Nombela-Arrieta C, Pivarnik G, Winkel B, Canty KJ, Harley B, Mahoney JE, Park SY, Lu J, Protopopov A, Silberstein LE. 2013. Quantitative imaging of haematopoietic stem 


\section{F. La Manna et al.}

and progenitor cell localization and hypoxic status in the bone marrow microenvironment. Nat Cell Biol 15: 533 543.

Nowell P. 1976. The clonal evolution of tumor cell populations. Science 194: 23-28.

Ocaña OH, Córcoles R, Fabra Á, Moreno-Bueno G, Acloque H, Vega S, Barrallo-Gimeno A, Cano A, Nieto MA. 2012. Metastatic colonization requires the repression of the epithelial-mesenchymal transition inducer Prrxl. Cancer Cell 22: 709-724.

Ottewell PD, Wang N, Meek J, Fowles CA, Croucher PI, Eaton CL, Holen I. 2014. Castration-induced bone loss triggers growth of disseminated prostate cancer cells in bone. Endocr Relat Cancer 21: 769-781.

Özdemir BC, Hensel J, Secondini C, Wetterwald A, Schwaninger R, Fleischmann A, Raffelsberger W, Poch O, Delorenzi M, Temanni R, et al. 2014. The molecular signature of the stroma response in prostate cancer-induced osteoblastic bone metastasis highlights expansion of hematopoietic and prostate epithelial stem cell niches. PLoS ONE 9: e114530-e114532.

Paget S. 1889. The distribution of secondary growths in cancer of the breast. Lancet 133: 571-573.

Palmgren JS, Karavadia SS, Wakefield MR. 2007. Unusual and underappreciated: Small cell carcinoma of the prostate. Semin Oncol 34: 22-29.

Pantel K, Speicher MR. 2015. The biology of circulating tumor cells. Oncogene 35: 1216-1224.

Pretlow TG, Delmoro CM, Dilley GG, Spadafora CG, Pretlow TP. 1991. Transplantation of human prostatic carcinoma into nude mice in Matrigel. Cancer Res 51: 3814-3817.

Pretlow TG, Wolman SR, Micale MA, Pelley RJ, Kursh ED, Resnick MI, Bodner DR, Jacobberger JW, Delmoro CM, Giaconia JM, et al. 1993. Xenografts of primary human prostatic carcinoma. J Natl Cancer Inst 85: 394-398.

Price TT, Burness ML, Sivan A, Warner MJ, Cheng R, Lee $\mathrm{CH}$, Olivere L, Comatas K, Magnani J, Kim Lyerly H, et al. 2016. Dormant breast cancer micrometastases reside in specific bone marrow niches that regulate their transit to and from bone. Sci Transl Med 8: 340ra73.

Rakhra K, Bachireddy P, Zabuawala T, Zeiser R, Xu L, Kopelman A, Fan AC, Yang Q, Braunstein L, Crosby E, et al. 2010. $\mathrm{CD}^{+} \mathrm{T}$ cells contribute to the remodeling of the microenvironment required for sustained tumor regression upon oncogene inactivation. Cancer Cell 18: 485-498.

Rentsch CA, Cecchini MG, Thalmann GN. 2009. Loss of inhibition over master pathways of bone mass regulation results in osteosclerotic bone metastases in prostate cancer. Swiss Med Wkly 139: 220-225.

Ruiz C, Lenkiewicz E, Evers L, Holley T, Robeson A, Kiefer J, Demeure MJ, Hollingsworth MA, Shen M, Prunkard D, et al. 2011. Advancing a clinically relevant perspective of the clonal nature of cancer. Proc Natl Acad Sci 108: 12054-12059.

Sankineni S, Brown AM, Fascelli M, Law YM, Pinto PA, Choyke PL, Turkbey B. 2015. Lymph node staging in prostate cancer. Curr Urol Rep 16: 30.

Sasaki A, Boyce BF, Story B, Wright KR, Chapman M, Boyce R, Mundy GR, Yoneda T. 1995. Bisphosphonate risedro- nate reduces metastatic human breast cancer burden in bone in nude mice. Cancer Res 55: 3551-3557.

Schardt JA, Meyer M, Hartmann CH, Schubert F, SchmidtKittler O, Fuhrmann C, Polzer B, Petronio M, Eils R, Klein CA. 2005. Genomic analysis of single cytokeratinpositive cells from bone marrow reveals early mutational events in breast cancer. Cancer Cell 8: 227-239.

Scherr DS, Vaughan ED, Wei J, Chung M, Felsen D, Allbright R, Knudsen BS. 1999. Bcl-2 and p53 expression in clinically localized prostate cancer predicts response to external beam radiotherapy. J Urol 162: 12-17.

Schneider A, Kalikin LM, Mattos AC, Keller ET, Allen MJ, Pienta KJ, McCauley LK. 2005. Bone turnover mediates preferential localization of prostate cancer in the skeleton. Endocrinology 146: 1727-1736.

Schneider JG, Amend SR, Weilbaecher KN. 2011. Integrins and bone metastasis: Integrating tumor cell and stromal cell interactions. Bone 48: 54-65.

Schwaninger R, Rentsch CA, Wetterwald A, van der Horst G, van Bezooijen RL, van der Pluijm G, Löwik CWGM, Ackermann K, Pyerin W, Hamdy FC, et al. 2007. Lack of noggin expression by cancer cells is a determinant of the osteoblast response in bone metastases. Am J Pathol 170: $160-175$.

Secondini C, Wetterwald A, Schwaninger R, Thalmann GN, Cecchini MG. 2011. The role of the BMP signaling antagonist noggin in the development of prostate cancer osteolytic bone metastasis. PLOS ONE 6: e16078.

Semenov M, Tamai K, He X. 2005. SOST is a ligand for LRP5/LRP6 and a Wnt signaling inhibitor. J Biol Chem 280: $26770-26775$.

Sherwood LM, Parris EE, Folkman J. 1971. Tumor angiogenesis: Therapeutic implications. $N$ Engl J Med 285: 1182-1186.

Shiozawa Y, Pienta KJ, Taichman RS. 2011. Hematopoietic stem cell niche is a potential therapeutic target for bone metastatic tumors. Clin Cancer Res 17: 5553-5558.

Shiozawa Y, Berry JE, Eber MR, Jung Y, Yumoto K, Cackowski FC, Yoon HJ, Parsana P, Mehra R, Wang J, et al 2016. The marrow niche controls the cancer stem cell phenotype of disseminated prostate cancer. Oncotarget 7: 41217-41232.

Siegel R, Ma J, Zou Z, Jemal A. 2014. Cancer statistics, 2014. CA Cancer J Clin 64: 9-29.

Sleeman J, Steeg PS. 2010. Cancer metastasis as a therapeutic target. Eur J Cancer 46: 1177-1180.

Smith MR, Egerdie B, Toriz NH, Feldman R, Tammela TLJ, Saad F, Heracek J, Szwedowski M, Ke C, Kupic A, et al. 2009. Denosumab in men receiving androgen-deprivation therapy for prostate cancer. $N$ Engl J Med 361: 745-755.

Sterling JA, Edwards JR, Martin TJ, Mundy GR. 2011. Advances in the biology of bone metastasis: How the skeleton affects tumor behavior. Bone 48: 6-15.

Sugatani T, Hruska KA. 2009. Impaired micro-RNA pathways diminish osteoclast differentiation and function. $J$ Biol Chem 284: 4667-4678.

Sugatani T, Vacher J, Hruska KA. 2011. A microRNA expression signature of osteoclastogenesis. Blood 117: 3648-3657. 
Sun Y-X, Schneider A, Jung Y, Wang J, Dai J, Wang J, Cook K, Osman NI, Koh-Paige AJ, Shim H, et al. 2004. Skeletal localization and neutralization of the SDF-1(CXCL12)/ CXCR4 axis blocks prostate cancer metastasis and growth in osseous sites in vivo. J Bone Miner Res 20: 318-329.

Thalgott M, Rack B, Horn T, Heck Mm, Eiber M, Kübler H, Retz M, Gschwend Je, Andergassen U, Nawroth R. 2015. Detection of circulating tumor cells in locally advanced high-risk prostate cancer during neoadjuvant chemotherapy and radical prostatectomy. Anticancer Res 35: 56795685.

Thalmann GN, Sikes RA, Devoll RE, Kiefer JA, Markwalder R, Klima I, Farach-Carson CM, Studer UE, Chung LWK. 1999. Osteopontin: Possible role in prostate cancer progression. Clin Cancer Res 5: 2271.

Thalmann GN, Sikes RA, Wu TT, Degeorges A, Chang SM, Ozen M, Pathak S, Chung LW. 2000. LNCaP progression model of human prostate cancer: Androgen-independence and osseous metastasis. Prostate 44: 91-103.

Theriault RL. 2012. Biology of bone metastases. Cancer Control 19: 92-101.

Thiery JP. 2002. Epithelial-mesenchymal transitions in tumour progression. Nat Rev Cancer 2: 442-454.

Tsai JH, Donaher JL, Murphy DA, Chau S, Yang J. 2012. Spatiotemporal regulation of epithelial-mesenchymal transition is essential for squamous cell carcinoma metastasis. Cancer Cell 22: 725-736.

Valastyan S, Weinberg RA. 2011. Tumor metastasis: Molecular insights and evolving paradigms. Cell 147: 275-292.

van den Hoogen C, van der Horst G, Cheung H, Buijs JT, Lippitt JM, Guzman-Ramirez N, Hamdy FC, Eaton CL, Thalmann GN, Cecchini MG, et al. 2010. High aldehyde dehydrogenase activity identifies tumor-initiating and metastasis-initiating cells in human prostate cancer. Cancer Res 70: 5163-5173.

van der Pluijm G. 2011. Epithelial plasticity, cancer stem cells and bone metastasis formation. Bone 48: 37-43.

van der Pluijm G, Que I, Sijmons B, Buijs JT, Lowik CW, Wetterwald A, Thalmann GN, Papapoulos SE, Cecchini MG. 2005. Interference with the microenvironmental support impairs the de novo formation of bone metastases in vivo. Cancer Res 65: 7682-7690.

Vanharanta S, Massagué J. 2013. Origins of metastatic traits. Cancer Cell 24: 410-421.

Wang G, Wang J, Sadar MD. 2008. Crosstalk between the androgen receptor and $\beta$-catenin in castrate-resistant prostate cancer. Cancer Res 68: 9918-9927. van Weerden WM, Romijn JC. 2000. Use of nude mouse xenograft models in prostate cancer research. Prostate 43: 263-271.

van Weerden WM, de Ridder CM, Verdaasdonk CL, Romijn JC, van der Kwast TH, Schröder FH, van Steenbrugge GJ. 1996. Development of seven new human prostate tumor xenograft models and their histopathological characterization. Am J Pathol 149: 1055-1062.

Wang X, Julio MK-D, Economides KD, Walker D, Yu H, Halili MV, Hu Y-P, Price SM, Abate-Shen C, Shen MM. 2009. A luminal epithelial stem cell that is a cell of origin for prostate cancer. Nature 461: 495-500.

Weilbaecher KN, Guise TA, McCauley LK. 2011. Cancer to bone: A fatal attraction. Nat Rev Cancer 11: 411-425.

Xiao Y, Woo WM, Nagao K, Li W, Terunuma A, Mukouyama YS, Oro AE, Vogel JC, Brownell I. 2013. Perivascular hair follicle stem cells associate with a venule annulus. J Invest Dermatol 133: 2324-2331.

Yang J, Weinberg RA. 2008. Epithelial-mesenchymal transition: At the crossroads of development and tumor metastasis. Dev Cell 14: 818-829.

Yuen KK, Shelley M, Sze WM, Wilt T, Mason MD. 2006. Bisphosphonates for advanced prostate cancer. Cochrane Database Syst Rev 12: CD006250.

Zellweger T, Ninck C, Bloch M, Mirlacher M, Koivisto PA, Helin HJ, Mihatsch MJ, Gasser TC, Bubendorf L. 2005. Expression patterns of potential therapeutic targets in prostate cancer. Int J Cancer 113: 619-628.

Zhang J, Niu C, Ye L, Huang H, He X, Tong W-G, Ross J, Haug J, Johnson T, Feng JQ, et al. 2003. Identification of the haematopoietic stem cell niche and control of the niche size. Nature 425: 836-841.

Zhang J, Zhao H, Chen J, Xia B, Jin Y, Wei W, Shen J, Huang Y. 2012. Interferon- $\beta$-induced miR-155 inhibits osteoclast differentiation by targeting SOCS1 and MITF. FEBS Lett 586: 3255-3262.

Zhao Y, Bachelier R, Treilleux I, Pujuguet P, Peyruchaud O, Baron R, Clement-Lacroix P, Clézardin P. 2007. Tumor v 3 integrin is a therapeutic target for breast cancer bone metastases. Cancer Res 67: 5821-5830.

Zheng X, Carstens JL, Kim J, Scheible M, Kaye J, Sugimoto H, Wu CC, LeBleu VS, Kalluri R. 2015. Epithelial-tomesenchymal transition is dispensable for metastasis but induces chemoresistance in pancreatic cancer. Nature 527: 525-530. 


\section{$\&_{\mathrm{CSH}}^{\infty} \&$ Cold Spring Harbor

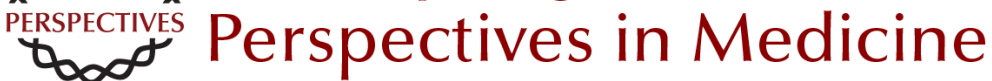

\section{Metastases in Prostate Cancer}

Federico La Manna, Sofia Karkampouna, Eugenio Zoni, Marta De Menna, Janine Hensel, George N. Thalmann and Marianna Kruithof-de Julio

Cold Spring Harb Perspect Med 2019; doi: 10.1101/cshperspect.a033688 originally published online April 16,2018

\section{Subject Collection Prostate Cancer}

Anatomic and Molecular Imaging in Prostate

Cancer

Eric T. Miller, Amirali Salmasi and Robert E. Reiter

The Epidemiology of Prostate Cancer

Claire H. Pernar, Ericka M. Ebot, Kathryn M. Wilson, et al.

Prostate Stem Cells and Cancer Stem Cells Jia J. Li and Michael M. Shen

Prostate Cancer Epigenetics: From Basic Mechanisms to Clinical Implications Srinivasan Yegnasubramanian, Angelo M. De Marzo and William G. Nelson

\section{The Genomics of Prostate Cancer: A Historic}

Perspective

Mark A. Rubin and Francesca Demichelis

Neuroendocrine Differentiation in Prostate

Cancer: Emerging Biology, Models, and Therapies Loredana Puca, Panagiotis J. Vlachostergios and Himisha Beltran

DNA Damage Response in Prostate Cancer Matthew J. Schiewer and Karen E. Knudsen

Transcriptional Regulation in Prostate Cancer David P. Labbé and Myles Brown
New Opportunities for Targeting the Androgen

Receptor in Prostate Cancer

Margaret M. Centenera, Luke A. Selth, Esmaeil Ebrahimie, et al.

Prostate Cancer Research at the Crossroads Michael M. Shen and Mark A. Rubin

Immunotherapy for Prostate Cancer Nicholas J. Venturini and Charles G. Drake

Molecular Pathology of High-Grade Prostatic Intraepithelial Neoplasia: Challenges and Opportunities

Levent Trabzonlu, Ibrahim Kulac, Qizhi Zheng, et al.

Metastases in Prostate Cancer Federico La Manna, Sofia Karkampouna, Eugenio Zoni, et al.

Genetically Engineered Mouse Models of Prostate Cancer in the Postgenomic Era Juan M. Arriaga and Cory Abate-Shen

Molecular Biomarkers in the Clinical Management of Prostate Cancer Aaron M. Udager and Scott A. Tomlins

Metabolic Vulnerabilities of Prostate Cancer:

Diagnostic and Therapeutic Opportunities Giorgia Zadra and Massimo Loda

For additional articles in this collection, see http://perspectivesinmedicine.cshlp.org/cgi/collection/ 